\title{
Leopoldo Lugones, el Estado equitativo y la sociedad militarizada. Una representación del autoritarismo argentino después del golpe de Estado de 1930*
}

\author{
Olga Echeverría \\ Universidad Nacional del Centro/CONICET \\ Argentina
}

Este artículo pretende abordar una problemática y un período no muy tenido en cuenta por los estudios existentes sobre la derecha autoritaria argentina de principios del siglo XX. Busca analizar la forma en que uno de los principales intelectuales antidemocráticos, Leopoldo Lugones, intentó superar la frustración provocada por el curso tomado por el gobierno iniciado con el golpe de Estado de 1930.

En ese sentido, si bien se reconoce la creciente intrascendencia política de los escritores autoritarios -incluido el propio Lugones-, se pretende poner en evidencia los esfuerzos intelectuales por recuperar una influencia que, según se percibía, se había gozado en los años previos al movimiento.

De alli que la representación del Estado y la sociedad que realizaba el poeta y hombre político constituyan un aspecto importante a tener en cuenta al momento de analizar su forma de entender la política y el pensamiento como acción.

Palabras Clave: Derecha autoritaria. Intelectuales. Antidemocráticos. Representación. Estado. Sociedad. Argentina.

This paper pretends to board a problematic and a period no very have in charge by the existing studies of the argentine authority right in the beginnings of XX century. This paper tries to analyse the way one of the main antidemocratic intellectuals, Leopoldo Lugones, tried to surpass the frustration that he felt due to the course that took the government initialised with 1930 coup d'état.

Although it is recognised the increasing politic intrascendence of the authorities writers, included Lugones, we pretend to point and to note the evidence, that the intellectual efforts to recover an influence that they had enjoined during the movement previous years. So, the representation of the State and of the Society that were imagined by the poet and at the same time, politic man are an important aspect to have in charge at the moment we analyse his way to understood the policy and the thinking task as action.

KEYWORDS: Authority right. Antidemocratic. Intellectuals. Representation. State. Society. Argentina.

* Este trabajo se inscribe en un proyecto mayor, que pretende estudiar la constitución de un grupo de escritores en referentes de la derecha autoritaria argentina en las primeras décadas del siglo $\mathrm{XX}$, atendiendo a sus perspectivas intelectuales, concepciones políticas, ideologías estéticas y representaciones sociales entre otras cuestiones. Una versión previa de este trabajo fue presentada en las Jornadas "Perspectivas históricas sobre el estado argentino", Universidad Nacional de Quilmes, junio de 2003. Agradezco los comentarios realizados por Darío Roldán y Mariano Plotkin. Reconozco la atenta lectura de la profesora Susana Bianchi y de la doctora Lucía Lionetti. 


\section{Introducción}

La crisis que afectó al mundo occidental desde fines del siglo XIX, agravada por el estallido de la primera gran guerra, repercutió fuertemente en la Argentina que, a su vez, se conmovía por su propia transformación resultante del proceso inmigratorio, la modernización y la instauración de la democracia mayoritaria. Todo esto, más la incapacidad de los sectores conservadores de conformar un partido orgánico estable que alejara los "riesgos de la democracia" llevó a que no fuesen pocos los hombres de la política y la cultura que, hacia los años veinte, comenzaron a alzar sus voces para denunciar el estado de descontrol y desborde social. Entre esa multiplicidad de expresiones disconformes, el escritor Leopoldo Lugones se constituyó en el precursor y paladín de la militarización y el autoritarismo, logrando, en cierta medida y no sin resistencias, aglutinar tras su figura referencial a un heterogéneo conjunto de escritores que se dedicaron a "crear ambiente" para la conspiración golpista. Eufóricos participaron de la asonada de Uriburu de 1930, pero la realidad les demostraría pronto que se presencia no era lo significativa y trascendente que habían imaginado. Así, y al poco andar debieron asumir esa inferioridad y tratar de elaborar nuevas estrategias de instalación y redefinir sus propuestas programáticas.

Este artículo busca aproximarse a algunos aspectos del ideario de Leopoldo Lugones posterior al golpe de Estado. Lugones fue una figura multiforme de la política y las letras de la Argentina, cuya alborotada vida política lo mostró como un personaje pintoresco, caracterizado por sus contradicciones. Sin embargo, es posible encontrar una coherencia en el pensamiento "lugoniano" y en sus definiciones políticas, tanto como un eje articulador de su ideología y de su experiencia, que se mantuvo, aunque resignificada, a lo largo de su trayectoria. ${ }^{1}$ En este sentido, considero que existió en Lugones un corpus de pensamiento que se manifestó en sus producciones intelectuales tanto de la juventud como de la madurez y que permite elaborar una explicación sobre su compleja trayectoria política. Su adhesión a proyectos políticos que muchas veces parecían opuestos pueden ser vistos como intentos de concreción de aquellos ideales fundantes de su experiencia e intereses. Su concepción política atendía fuertemente a lo

1 Por razones de espacio no puedo extenderme en este análisis, que he realizado en otros trabajos anteriores. Por ejemplo, "Leopoldo Lugones: el disruptivo proyecto elitista y autoritario de un hombre solo. Argentina, primeras décadas del siglo XX”, en prensa. 
pragmático, aunque nunca renunciase definitivamente a los principios y definiciones ideológicas. Su cosmovisión del mundo se mantuvo, en buena medida, inalterada a lo largo de cuatro décadas, pero no así los caminos para su concreción, que fueron ganando paulatinamente definiciones más precisas y programas mejor estructurados, si bien nunca alcanzaron una argumentación filosófica verdaderamente sólida.

En este sentido es que me interesa rastrear aquí la representación del Estado y la sociedad que hacía con posterioridad al golpe de Estado de 1930. Entiendo que analizar este período, no muy tenido en cuenta en los trabajos que abordan la problemática del llamado "nacionalismo" argentino, es relevante por dos cuestiones centrales. Por un lado, permite conocer la forma como los intelectuales autoritarios, en este caso Lugones, asumieron el fracaso del proyecto uriburista (o quizás sea más oportuno decir, de lo que ellos pretendían que representara el gobierno del General José Félix Uriburu) y como intentaron revertir la irrelevancia de sus perspectivas e influencias. Las propuestas de Lugones ${ }^{2}$ que se analizarán en este artículo revelan claramente los intentos de reinstalarse en el escenario político argentino, de revertir el aislamiento y de manifestar la existencia de una forma de entender la política disconforme con la vigente. Por otro lado, y directamente relacionado con lo anterior, el Estado equitativo proyectado por Lugones entre 1931 y 1932 acredita un esfuerzo argumentativo y una reflexión más aguda que la evidenciada en tiempos de mayor optimismo y euforia. Desde esa faceta, y dado el interés que tiene lo intelectual para este trabajo, es también significativo evaluar ese desarrollo del pensamiento, aun cuando en términos más estrictamente políticos la influencia se encontrara en declive. ${ }^{3}$

Leopoldo Lugones, fue, indudablemente, un escritor preocupado por las cuestiones políticas desde sus comienzos mismos como poeta y tuvo, a lo largo de su vida, una influencia importante al menos como portador de

2 He analizado el recorrido de otros referentes de esta misma línea ideológica, en el período posterior al golpe de Estado de 1930, en Olga Echeverría: "De la apelación antidemocrática al colonialismo como argumento impugnador de la "oligarquía": los hermanos Irazusta en la génesis del Revisionismo histórico argentino", Revista Prohistoria, en prensa, y en: "Carlos Ibarguren: de la reforma controlada de la política al control autoritario de la sociedad. El camino de un proyecto fracasado", inédito.

3 Los intelectuales elitistas, que acompañaron el golpe de Estado de 1930 y que previamente habían encarado con ahínco la campaña conspirativa, se sintieron prontamente frustrados. Ese hecho los obligó a redefinir sus proyectos y a volver más evidentes las diferencias entre todos ellos. Sin duda, la euforia de lo que parecía una victoria segura había disimulado las tensiones entre perspectivas y propuestas que cruzaban a este heterogéneo grupo. 
un discurso disruptivo y provocador. ${ }^{4} \mathrm{Su}$ actividad se desarrolló en el campo intelectual y en el campo político simultáneamente, sin que pueda considerarse que uno de esos campos fuera predominante. Aunque siempre quedó claro que su identidad se articulaba en torno a la imagen de un intelectual esclarecido y esclarecedor que sostenía que su función - en tanto pensador- era ordenar y guiar a la sociedad. Fue indiscutido precursor del nacionalismo cultural y también un escritor reconocido y celebrado prácticamente desde los inicios mismos de su actividad literaria, asumiéndose, y asumido, como el poeta de la nacionalidad. Sin embargo, y más allá de sus críticas para con las políticas del Estado, y por razones de subsistencia, también fue el ejemplo más evidente de escritor oficial. Este padrinazgo del Estado fue, sin duda, como para muchos otros escritores, una protección de doble filo, pues al mismo tiempo que le garantizaba la subsistencia lo apresaba en una máquina de cooptación. Precisamente por esto Lugones mostró un esfuerzo permanente por presentarse y aparecer como un intelectual no institucionalizado, que hablaba desde una perspectiva autónoma de las instituciones oficiales, aunque su pensamiento se sustentaba en un pragmatismo de inmediata aplicación social.

4 Leopoldo Lugones había nacido en 1874, en Villa María del Río Seco (provincia de Córdoba, República Argentina), pero pasó buena parte de su infancia en la provincia de Santiago del Estero, ya que su familia poseía una estancia en los límites de ambas provincias, gozando de cierto prestigio social basado en la posesión de tierras y en alguna vinculación con los sectores dominantes. Situación privilegiada que provenía, según el propio Lugones, desde los tiempos de la colonia debido a "los servicios públicos de sus antepasados". Sin embargo, y como resultado de la crisis económica de 1890, la familia perdió la propiedad de sus campos y debió trasladarse a la vivienda de la abuela materna en la ciudad de Córdoba. Desde entonces, y producto de esa modificación del status económico, el joven Leopoldo debió insertarse en el mundo laboral, siendo inicialmente empleado del municipio cordobés y más tarde administrativo dependiente del ámbito de correos. Este hecho, entiendo, marcó vivamente al espíritu de Lugones, un excluido de la elite dominante y potencialmente en los "bordes" de la elite cultural del país, ya que tampoco recibió ninguna educación formal y no dispuso de los medios económicos para vivir dedicado a la literatura, ni para realizar el consabido viaje iniciático a Europa, que cumplían, sin excepción, los jóvenes acomodados de la Argentina agro exportadora. Dio sus primeros pasos en el periodismo como redactor del periódico anticlerical El Pensamiento Libre, y en la militancia política al sumarse, como miembro voluntario, a la Guardia Nacional. En ésta fue designado para reprimir los alzamientos de los radicales rosarinos. Hacia 1894 comenzó a publicar su obra literaria temprana en periódicos cordobeses bajo el seudónimo de Gil Paz, y, a partir del año siguiente, participó de las protestas sociales de la región y fundó un centro socialista. Ya en 1896 se trasladó a Buenos Aires, donde ingresó al agitado universo del periodismo capitalino y se vinculó con los también jóvenes y promisorios intelectuales socialistas: José Ingenieros y Roberto J. Payró. Ese mismo año Rubén Darío saludó el nacimiento de un gran poeta, al escuchar algunos poemas escritos por Lugones. Comenzaba su legitimación dentro del campo intelectual. Unos meses después, en 1897, publicó junto a José Ingenieros La Montaña, periódico socialista revolucionario, que se editó entre el primero de abril y el 15 de septiembre de 1897 . 
Si bien su desarrollo temprano lo llevó a participar del socialismo ${ }^{5}$ y de un periódico anticlerical, pasando más tarde por una militancia a favor de Roca y Quintana, referentes del liberal conservadurismo argentino, ${ }^{6}$ su madurez transcurrió entre manifestaciones autoritarias, antidemocráticas, militaristas y críticas con la élite burguesa. Por entonces, hacia las décadas de 1920 y 1930, Lugones se convirtió en la figura referencial y aglutinante de todos aquellos intelectuales que compartían una atmósfera ideológica autoritaria y que englobaban sus consideraciones del pasado y sus perspectivas sobre el futuro bajo el rótulo del nacionalismo. En ese conglomerado articulado por una "estructura del sentir", 7 la relación no fue sencilla, ni armónica. ${ }^{8}$ Así, el poeta cordobés fue centro del debate interno y no pocas veces fue cuestionado con dureza. Sin embargo, también era estandarte de presentación y legitimación externa de ese impreciso y heterogéneo núcleo. ${ }^{9}$ Se trataba, entonces, de un Lugones que ocupaba, simbólica y

5 Considero que la breve militancia socialista podría ser pensada, más que como una apuesta a favor de los trabajadores, como resultado de una vocación radicalmente antiburguesa.

6 Los llamados liberales argentinos debieron conciliar su preocupación por el establecimiento de los derechos individuales con la construcción del Estado-nación, lo cual llevó, como sostiene Zimmermann, a posiciones doctrinarias y políticas por lo menos ambiguas. Por ello, liberalismo y conservadurismo en Argentina fueron muchas veces características complementarias más que opuestas de un sistema político. Véase: Zimmermann, Eduardo: Los liberales reformistas. La cuestión social en la Argentina, 1890-1916, Sudamericana, Buenos Aires, 1995, págs. 41-42. Para aproximarse a las características de esta elite, también pueden consultarse: Botana, Natalio: El orden conservador. La política argentina entre 1880-1916, Hyspamerica, Buenos Aires, 1986; Balmori, Diana, Voss, Stuart F. y Wortman, Miles: Las alianzas de familias y la formación del país en América Latina, FCE, México, 1990, y Bonaudo, Marta y Sonzogni, Élida: "Redes parentales y facciones en la política santafesina, 1850-1900”, en Siglo XIX, N. ${ }^{\circ} 11$, enero-junio de 1992, entre otros.

7 Williams, Raymond: Marxismo y literatura, Península, Barcelona, 1980, págs. 154-155.

8 Podría decirse que era imposible que los vínculos entre los intelectuales elitistas fueran integrales, ya que esta corriente estaba unida de manera muy laxa por una voluntad autoritaria y despectiva con lo plebeyo, pero involucraba a escritores de muy diversas tendencias y expectativas como por ejemplo los jóvenes maurrasianos — aunque republicanos - que comandaban los hermanos Irazusta y Palacio, sectores católicos orgánicos aglutinados en torno a la revista Criterio, católicos autónomos como Manuel Gálvez y ex referentes del liberalismo conservador como Carlos Ibarguren. Compartían un diagnóstico radicalmente crítico de la experiencia democrática, pero las discrepancias de sus mociones para superar "ese caos" eran lo suficientemente fuertes como para hacer abortar todo tipo de organización o propuesta conjunta.

9 Sobre el autodenominado nacionalismo argentino existen una buena cantidad de trabajos: los ya clásicos de Mcgee Deutch, Sandra: Counterrevolution in Argentina, 1900-1932: The Argentine Patriotic League, University of Nebraska Press, Lincoln, 1986; Mcgee Deutsch y otros: La derecha Argentina, Vergara editores, Buenos Aires, 2001; Navarro Gerassi, Marysa: Los Nacionalistas, Jorge Álvarez, Buenos Aires, 1969; Barbero, María Inés y Devoto, Fernando: Los nacionalistas, CEAL, Buenos Aires, 1983, entre otros; y los más recientes y con perspectivas de análisis que reflejan con mayor claridad la heterogeneidad de esta corriente: Devoto, Fernando: Nacionalismo, fascismo y tradicionalismo en la Argentina moderna, Siglo XXI de Argentina, Buenos Aires, 2002, y Halperín Donghi, Tulio: 
efectivamente, una posición dominante en el campo político de la derecha y en el campo intelectual argentino. ${ }^{10}$

A lo largo de toda su vida pública proclamó la superioridad de los intelectuales, a quienes consideraba esencialmente diferentes —en tanto individuos aventajados - al resto de la sociedad. ${ }^{11}$ De tal modo, los intelectuales, esos personajes sociales que unían, en su perspectiva, heroicidad y poesía, debían ocupar las áreas primordiales del poder para lograr el desarrollo económico y estético de la sociedad y la nación.

La primera guerra mundial significó para Lugones, como para tantos otros, un punto de inflexión insoslayable. La transformación radical del mundo occidental lo llevó a agudizar su mirada crítica sobre la política y la cultura y lo impulsó a tratar de organizar una reflexión coherente e integral, que trataba de evidenciar la crisis de la civilización occidental y de la Argentina en particular. ${ }^{12}$ A partir de entonces, e iniciando un proceso de convencimiento de la decadencia definitiva del liberalismo, comenzó a ensayar respuestas políticas y sociales que reordenaran el mundo y establecieran las jerarquías que él consideraba indispensables para el funcionamiento organizado de la comunidad.

Como sucedió con los otros referentes de la derecha autoritaria que lo siguieron en su crítica antidemocrática, es posible pensar que la apelación a un orden nuevo era resultante de una frustración relativa. Es decir, desarrollada a partir de una experiencia que experimentaba la insatisfacción de sus expectativas, no sólo en términos personales e inmediatos, sino también sectoriales, políticos y sociales.

\footnotetext{
La Argentina y la tormenta del mundo, Siglo XXI, Buenos Aires, 2003. Todos ellos, y mi propia tesis doctoral: "Una inteligencia disciplinada y disciplinante". Los intelectuales autoritarios de derecha: su concepción estética-ideológica, la política y la representación de la sociedad. Argentina, primeras décadas del siglo XX, Doctorado Inter. Universitario en Historia, 2002, ponen en evidencia la complejidad de la derecha autoritaria argentina tanto como las múltiples influencias y readaptaciones de los idearios del período.

10 Sobre esta cuestión es necesario remitirse a Bourdieu, Pierre: "Campo intelectual y proyecto creador" en AAVV: Problemas del estructuralismo, Siglo XXI, México, 1967. Para el análisis particular de la conformación del campo cultural argentino el trabajo clave es el de Altamirano, Carlos y Sarlo, Beatriz: "La Argentina del centenario: campo intelectual, vida literaria y temas ideológicos", en Altamirano, Carlos y Sarlo, Beatriz: Ensayos argentinos. De Sarmiento a la Vanguardia, Ariel, Buenos Aires, 1997.

11 Ya en 1897 reclamaba un lugar de privilegio para los artistas e intelectuales. Véase "Los apóstoles de la Nueva era", La Montaña 1, 1 de abril de 1897, págs. 24-25, Edición Facsimilar, Universidad Nacional de Quilmes, Bernal, 1997.

12 Similar consideración remarca Zuleta Álvarez, Enrique: El nacionalismo argentino, La Bastilla, Buenos Aires, Tomo 1, 1969, pág. 118
} 
Es decir, la articulación del autodenominado nacionalismo partía de una experiencia compartida, del desplazamiento sufrido, o por lo menos así percibido, por la democratización política y social de la Argentina, pero también por la consolidación de una "clase política" excluyente. ${ }^{13}$

La crisis del liberalismo occidental, el triunfo bolchevique de 1917, el gobierno de Yrigoyen y su supuesta representación de las clases medias, la reforma universitaria argentina de 1918 y los violentos sucesos obreros de la Semana Trágica operaron como elementos, sino determinantes, al menos centrales para la definición autoritaria de muchos escritores argentinos, y en particular de Leopoldo Lugones. Determinación que, entiendo, estuvo guiada por el temor que generaba la percepción de que el universo se trastocaba precipitadamente. Así, y ante lo que consideraba el evidente fracaso de una civilización, ${ }^{14}$ pero también de un plan personal de instalación como promotor de la nación y tutor de la sociedad, canalizó sus frustraciones en la diatriba a la democracia y se orientó hacia la conformación de una experiencia autoritaria. ${ }^{15}$ Todo parecería mostrar que en esta etapa Lugones vio desvanecerse el universo que él había intentado construir/se y entendió que en una sociedad articulada culturalmente, como la Argentina de la democracia mayoritaria, sólo le aguardaba un destino profeta al que nadie estaba dispuesto a escuchar y seguir. No sin pesimismo, declaró al respecto: "las escasas ilusiones que hasta entonces pude abrigar sobre mi ingenio político, desvaneciéronse ante una realidad ciertamente útil para mi filosofía". ${ }^{16}$

De tal forma, y ya iniciada la década de 1920, Lugones se convirtió en el paladín del autoritarismo y en el más entusiasta pregonero de la solución militar. ${ }^{17}$ Para ello desarrolló una intensa campaña de agitación, y de auto instalación, en el escenario político. ${ }^{18}$

13 No se trataba, principalmente, de un cuestionamiento a la supuesta renovación de los funcionarios que había implicado la llegada de la Unión Cívica Radical al gobierno, sino de una crítica a la forma en que la élite liberal conservadora que había conducido a la Argentina antes de la reforma electoral de 1912 y que había recuperado el poder tras el golpe de Estado de 1930. Desde esta emergente derecha autoritaria las voces se alzaban para cuestionar la falta de objetivos trascendentes de esa dirigencia, sus manejos corruptos, el monopolio del acceso a las estructuras burocráticas del Estado y su mediocridad intelectual, tanto como su sometimiento a intereses e ideologías foráneas.

14 Véase Lugones: La Torre de Casandra, Atlántida, Buenos Aires, 1919, Prólogo.

15 Lugones: La Torre de Casandra, Prólogo.

16 Lugones: La Torre de Casandra, Prólogo.

17 Los trabajos que analizan a Leopoldo Lugones en tanto hombre político son: Navarro Gerassi: Los Nacionalistas...; Rock, David: La Argentina autoritaria. Los nacionalistas, su historia y su influencia en la vida pública, Ariel, Buenos Aires, 1993; Rock, David: "Intellectual Precursors of Conservative Nationalism in Argentina, 1900-1927”, en Hispanic American Historical Review, 67-2, 
Considero que buena parte de la apelación "lugoniana", presente en muchas otras figuras sociales de las vanguardias, reflejaba en principio una concepción de la violencia como medio purificador. Sólo la virtud militar, decía Lugones, podía llevar a una vida superior de belleza, orden y fuerza: los opuestos absolutos al caos, vulgaridad y feminización que expresaba la democracia. Su veneración de la potencia y su concepción de la violencia como arma purificadora se evidenciaban cuando sostenía que: "Ante la democracia ideológica y siempre falaz de los derechos del hombre, se alza ahora la realidad de la nación. Ante el gobierno consentido, el mando. Ante el racionalismo, la disciplina. Ante la libertad de las fórmulas, el bienestar de los hechos. Porque libre y justo, solo puede serlo el sano y el fuerte". ${ }^{19}$

Para Lugones, la autoridad era privilegio de los "mejores" y según señalaba reiteradamente era necesario imponer "la superioridad personal" ya que no concebía "al jefe sino en el general o en el caudillo". ${ }^{20}$

En los años transcurridos desde que se adjudicó el papel de portavoz e ideólogo del autoritarismo militar y hasta que finalmente se produjeron los sucesos de septiembre de 1930, Lugones se afianzó en su función de intelectual legitimador y propagandista de un orden diferente al modelo liberal-democrático. En su papel de doctrinario desenvolvió su accionar en un abanico de planos. Por un lado, utilizó el reconocimiento que su talento había ganado para difundir socialmente el proyecto que él sostenía. Por otro lado, aunque vinculado al punto anterior, usufructuó su prestigio para reclutar adherentes y militantes - tanto civiles como militares - para las propuestas ideológicas de la nueva derecha.

La campaña antidemocrática se reforzó con la llegada de Yrigoyen a la casa de gobierno para iniciar su segundo período presidencial, a las con-

mayo de 1987, Buchrucker, Cristian: Nacionalismo y peronismo. La Argentina en la crisis mundial, 1927-1955, Sudamericana, Buenos Aires, 1987; Barbero y Devoto: Los nacionalistas...; Devoto: Nacionalismo... Debo hacer notar que la mayoría de estos estudios detienen su estudio en los sucesos estrictamente vinculados con el golpe de Estado de 1930.

18 La primera expresión explícita de su definición autoritaria la brindó en las conferencias dictadas en el teatro Coliseo entre el 6 y el 17 de julio de 1923, auspiciado por la Liga Patriótica Argentina y el Círculo Tradición Argentina, y más tarde compilados en el libro Acción. Al año siguiente, pronunció el muy difundido discurso de Ayacucho conocido como "La hora de la espada", donde ya reivindicaba, sin ambigüedades, la acción del ejército que implantaría la jerarquía indispensable para derrocar "la nefasta trilogía de pacifismo, colectivismo y democracia", Lugones, Leopoldo: "El discurso de Ayacucho", en La Patria Fuerte, Edición del Círculo Militar, Buenos Aires, 1930, pág. 194 y ss.

19 Lugones: La Patria Fuerte, págs. 70-71.

20 Lugones: La Patria Fuerte, pág. 229. 
ferencias se sumaron los escritos periodísticos y un paulatino acercamiento a otros intelectuales (y también a militares) que apostaban a dar por terminada la experiencia democrática yrigoyenista. Desde entonces y hasta que se produce el golpe militar, el 6 de septiembre de 1930, la conspiración parece haber ocupado el pensamiento y la vida pública de Lugones.

Sin embargo, el movimiento mismo fue esencialmente militar y la mayoría de los escritores autoritarios resultaron acompañantes subsidiarios del gobierno provisional que emergió del golpe militar. En algunos casos, fue su propia actitud, aun eufórica, la que los hizo ocupar esa posición de escoltas - expectantes y deseosos de marcar rumbos- del nuevo orden y no un reconocimiento oficial a su agitación conspirativa. Lo cierto es que las expectativas que las diferentes personalidades y grupos se habían forjado, incluido Lugones, fueron desmerecidas por la realidad que los relegó al plano de publicistas, o, en el mejor de los casos, a algún cargo de relativa trascendencia. ${ }^{21}$ Como consta en la mayoría de los relatos sobre los sucesos del 6 de septiembre, los militares capitalizaron todo el descontento y la campaña de agitación previa en su favor, y utilizaron los argumentos intelectuales que se habían esgrimido desde un tiempo atrás para legitimar su accionar. Enrique Zuleta Âlvarez señala que el golpe de estado, como tal, fue una operación estrictamente castrense, donde la actuación de los "nacionalistas" se limitó a contribuir con la creación del clima político adverso a Yrigoyen en la misma medida en que lo hicieron otros grupos políticos no yrigoyenistas, desde los conservadores y los radicales antipersonalistas hasta los socialistas y comunistas. ${ }^{22}$

Es significativo recordar además que el gabinete estuvo integrado mayoritariamente por hombres del conservadurismo, representantes de la vieja elite de poder que había gobernado Argentina por largos años. Hecho

21 Carlos Ibarguren y Leopoldo Lugones escaparon relativamente a esa condena al anonimato y la absoluta intrascendencia; Ibarguren fue designado interventor federal en la Provincia de Córdoba; sin embargo, sus vínculos políticos —e incluso su parentesco con Uriburu- podrían haber sido considerados a la hora de la designación más determinantes que su trayectoria intelectual. Lugones, especie de vocero inicial de Uriburu, fue una figura conocida del entorno presidencial aunque nunca se le asignaron tareas de importancia Por su parte, Ernesto Palacio, de La Nueva República, fue designado en un cargo menor en la provincia de San Juan.

22 Zuleta Álvarez, Enrique: El nacionalismo argentino, La Bastilla, Buenos Aires, 1969, pág. 239. Si bien en líneas generales esta afirmación no deja de ser cierta, es necesario matizarla y dejar en claro que la naciente derecha autoritaria argentina compartía con ese amplio abanico político las críticas a la desorganización administrativa y a la prepotencia política del presidente Yrigoyen, pero se distanciaba de los socialistas en sus críticas al sistema democrático, en su desprecio a las masas y por supuesto en la reivindicación de una sociedad jerárquica y elitista. 
que, obviamente, no pasó desapercibido para los intelectuales autoritarios que prontamente expresaron sus disgustos y reclamos. El propio Lugones se quejó, en más de una oportunidad, de que los políticos habían usufructuado una revolución que, según su perspectiva, se había hecho contra ellos. Sin embargo, aún disconforme, no dejó de considerarse parte de ese "glorioso proyecto" y su propósito, en los años siguientes, fue el de construirse como ideólogo que encaminara y ordenara la reforma política de la Argentina. Ese giro, entendía, era lo único que iba a devolver el sentido a los sucesos de septiembre de 1930, y también un lugar trascendente a él mismo. De esa cuestión me ocuparé en las páginas que siguen.

\section{Leopoldo Lugones: militarismo y corporativismo político. Un proyecto que miraba hacia el futuro}

Apenas producido el golpe de Estado de 1930, Lugones reivindicaba orgulloso sus aciertos de profeta intelectual y celebraba la llegada al gobierno del "jefe predestinado" que tantas veces había anunciado y reclamado para el "bien de la nación". ${ }^{23}$ Sostenía que la "revolución" de septiembre era una obra del ejército, única institución capaz de hacerlo por "su disciplina más fuerte, su preparación más sólida, su conducta más limpia, su patriotismo más exigente, y aquella superior eficacia administrativa". ${ }^{24}$

Los militares eran así considerados la mano ejecutora indispensable. Sin embargo, siempre individualista, él reivindicaba para sí mismo el papel de ideólogo, y recordaba que hacía largos siete años venía pretendiendo la reestructuración del Estado, que había sido también él, y sólo él, quien había planteado con claridad los caminos que debían seguirse para anular la fatal influencia del "izquierdismo" 25 y había diseñado un programa político de gobierno, tanto como de organización política, cuando todos los demás se seguían sometiendo —y beneficiando mezquinamente-a las "delicias del voto universal".

23 Sobre su actuación previa al golpe de Estado de septiembre de 1930 puede verse Echeverría: "Leopoldo Lugones: el disruptivo proyecto...".

24 Lugones, Leopoldo: Política revolucionaria, Anaconda, Buenos Aires,1931, pág. 7.

25 La palabra "izquierdismo" resumía y sintetizaba la idea de enemigo que tenía Lugones. Pero el término no abarcaba solamente a las ideologías socialistas y anarquistas, sino que incluía, asimismo, al radicalismo -izquierdista desde su "obrerismo"- e incluso ciertas prácticas del régimen liberal que por desidia o confusión filosófica habían engendrado y dejado crecer esa ideología. 
En este sentido, mantenía cerrada coherencia con su pensamiento anterior, ya que continuaba reclamando la cima de la jerarquía política para los intelectuales, quienes no necesitaban involucrarse en funciones administrativas para imponer su dominio. ${ }^{26}$ Los militares, y más precisamente su jefe, el general Uriburu, fueron entonces presentados como ejecutores mucho más eficientes que los "predilectos del sufragio universal" dado que, según Lugones, en seis meses de gobierno habían logrado, a pesar de la crisis, reordenar la economía, restableciendo el crédito, reajustar la administración pública, eliminar al "extranjero pernicioso" que formaba dentro del país un verdadero "ejército de ocupación con bandera roja", combatir la delincuencia y fomentar, tanto como defender, el bienestar común. $^{27}$

Es interesante señalar que Lugones mostraba -mientras duró la euforia por septiembre- una preocupación casi exclusiva por las cuestiones políticas, al mismo tiempo que al momento de pensar el reordenamiento de la sociedad también apelaba con exclusividad a la reforma política. Es decir, reorganizando radicalmente al Estado, entendía Lugones, se estructuraba de manera directa la sociedad bajo los parámetros del orden y la disciplina. Se trataba de una propuesta que decía estar más allá de la política, inspirada en un objetivo de orden superior como era el engrandecimiento de la nación. En esta crítica a la política, a diferencia de los otros representantes de la derecha autoritaria argentina, englobaba a prácticamente todo el régimen liberal ${ }^{28}$ y no solo a la experiencia yrigoyenista. Por lo tanto, sostenía que el movimiento iniciado el 6 de septiembre implicaba un proyecto revolucionario, de transformación radical de la Argentina que hacía que los liberales en su conjunto se hubieran vuelto conservadores y reaccionarios, defendiendo al viejo orden derrotado por las "armas de la nación".

La política estaba "infestada de izquierdismos y conveniencia electoral". Si bien el golpe de septiembre había logrado una victoria momentánea sobre ella, el peligro se mantenía latente. De allí, los denodados esfuerzos - puestos en palabras - que realizó los meses siguientes al movimiento militar para descalificar la realización de elecciones en un

26 En este contexto puede enmarcarse, quizás, su rechazo al cargo ofrecido. Aunque también podría pensarse que la Dirección de la Biblioteca Nacional no satisfacía sus expectativas.

27 Lugones: Política Revolucionaria..., pág. 8.

28 Con la sola excepción de Roca, pues él sostenía que el carácter militar de este general había sido muy beneficioso para la patria. 
futuro próximo y bajo el imperio de la ley Sáenz Peña. En su argumentación explicaba que, sin un restablecimiento moral y material de la disciplina, se corría el riesgo seguro de volver a la anarquía, e incluso de resucitar el personalismo yrigoyenista.

En este sentido, y a pesar de la entusiasmada reivindicación de los sucesos acaecidos y del propio general Uriburu, se puede advertir cuál era la lucha política de Lugones dentro del elenco heterogéneo que acompañaba al gobierno: marcar un rumbo de tendencia corporativa sustentado por una profunda metamorfosis política. Por ello, esgrimió gran voluntad para argüir a favor de la reorganización del sistema político y las formas de representación.

En ese camino, arremetió contra la Constitución al sostener que la misma era un producto extranjero, que debía ser reemplazado por una carta orgánica "más argentina" que asegurara una administración y una representación más eficaces y menos costosa para el gasto público, una prescripción más imperiosa del deber y un ideal menos vago y más positivo: un ideal de Patria y no de humanidad, siendo que sólo aquella, la nación, era una entidad política. La grandeza de la revolución, afirmaba, sólo sería efectiva si se resolvía de manera inmediata "la crisis constitucional", si se transformaba radicalmente la organización política del país. Así, una constitución que no se correspondía con los intereses y características nacionales solo podía apelar, para sobrevivir, a un subterfugio que sostenía que la letra era más valiosa que los propios hombres.

Es decir, que su propuesta, en la que insistió con vehemencia, se sustentaba en una organización abiertamente corporativa, donde "todo ciudadano mayor de edad sería, pues, elector; pero sólo podría ejercer su derecho cuando trabajara personal y continuamente en cualquier oficio, carrera o actividad civil, por supuesto que con las naturales excepciones del paro forzoso y de la inutilación legal. La calificación del voto consistiría, pues en la capacidad productora y estribaría en el concepto de la igualdad ante el trabajo, desde la tarea del jornalero hasta la invención del sabio y del artista: el que no trabaja no vota; desechando a la vez el derecho incondicional, una paradoja de la anarquía y la condición intelectualista del saber o no leer: prejuicio de los ideólogos liberales".$^{29}$

Esta "representación funcional" se imponía por las características geográficas, étnicas y culturales del país y no era, según el mismo sos-

29 Lugones: Política Revolucionaria..., págs. 46-47. 
tenía, simple imitación del modelo fascista. Podría decirse que el autor especificaba que si la organización terminaba teniendo algunas características fascistas, esto se debería a las exigencias de la propia realidad argentina, y no por adhesión a un modelo ideológico preestablecido. Se trataba, afirmaba, de dar preferencia a la política económica por encima de la electoral, ${ }^{30}$ hacer predominar a la fuerza sobre el consentimiento, la necesidad sobre la legalidad y la eficacia sobre la lógica. ${ }^{31}$ Evidentemente, la experiencia fascista estaba en el horizonte de la reflexión de Lugones, como de algunos otros hombres de las derechas argentinas, pero no era el único modelo que tenía en cuenta Lugones. ${ }^{32}$ Es decir, la vinculación con el fascismo era limitada y no se trataba de una adscripción teórica, ya que no implicaba una preocupación analítica profunda, ni la elaboración de un pensamiento comparable con los desarrollos especulativos sobre el corporativismo que habían explayado los intelectuales fascistas italianos. En todo caso, constituía una afinidad emotiva que se sustentaba, en buena medida, en los esperanzadores logros que obtenía Mussolini en Italia, pero que también expresaba disidencias que se basaban, por ejemplo, en una profunda desconfianza a la movilización de masas, en un explícito rechazo a las políticas y prácticas antisemitas y en un evidente gusto por cierta distinción "aristocrática".

En 1932, tras el fracaso del proyecto "uriburista" —o lo que inicialmente creyeron los intelectuales de la derecha autoritaria que ese gobierno representaba y pretendía instaurar-, Lugones publicó El Estado equitativo, que podría calificarse como su análisis más completo $-\mathrm{y}$ también su última reflexión de importancia al respecto- - de la realidad

30 Leopoldo: Política Revolucionaria, pág. 47.

31 Leopoldo: Política Revolucionaria, págs. 53-54.

32 Este escritor multiforme que fue Lugones recortaba y articulaba idearios que sólo cobran unidad en su propio corpus de pensamiento. A la ya reconocida influencia de cierto Nietzsche, habría que sumar sus encuentros ideológicos con Sorel. Tampoco se puede desconocer que sus censuras a la política recuerdan ciertos planteos de Primo de Rivera y que buena parte de sus esbozos de desarrollo nacional están inspirados en los logros de los Estados Unidos. Para analizar la complejidad de su pensamiento y su intrincado recorrido político e intelectual, me atrevo a recomendar algunos trabajos míos: "El pensamiento como acción. Leopoldo Lugones y su marcha hacia el autoritarismo elitista militar", ponencia presentada en IV Jornadas Internacionales de Historia Política, Mar del Plata, 16 de octubre de 1997; "La derecha autoritaria argentina en sus orígenes. Leopoldo Lugones: paladín de una corriente heterogénea”, en Publicación II Encuentro de Investigadores, Facultad de Ciencias Humanas, UNICEN, en prensa, y el ya citado "Leopoldo Lugones: el disruptivo proyecto...". 
argentina contemporánea, así como su propuesta corporativa más estudiada. ${ }^{33}$

A lo largo de este libro, la cuestión económica, tanto en diagnósticos como en proyectos, ocupaba un lugar importante en la reflexión, mostrando el interés particular de Lugones por esa problemática y el primer intento, más o menos sistemático, de la heterogénea corriente por abordar cuestiones que sobrepasaran la esfera política, y en particular la de la formas de gobierno. Sus planteos económicos eran coherentes y estaban claramente articulados con sus premisas político-sociales. Dentro de sus iniciativas refundacionales, el desarrollo económico era imprescindible, constituía una pieza clave e irrenunciable para el desenvolvimiento de un país poderoso. Pero, para que esa expansión fuese posible se requería de un Estado interventor que recuperase la armonía y reestableciera el orden y el bienestar económico de la población. ${ }^{34}$

Ningún interés privado, ya fuese individual o colectivo podía comprometer el bienestar común. Y, era allí donde el Estado debía estar para asegurar ese orden, pero también para diseñar los proyectos, planificar la producción, asegurar una comercialización ventajosa para la nación. Esta implantación del Estado interventor, advertía el ideólogo, se estaba llevando adelante incluso en los dos países más liberales del mundo: Estados Unidos de América y Gran Bretaña. En ambos casos, decía Lugones, se había comprendido que era necesario gobernar la producción y el comercio, pues una y otro eran actividades sociales. Así, cuando analizaba la situación argentina, hacía hincapié en la consideración de que los males

33 Considero que este libro puede ser entendido como un renovado esfuerzo de Lugones por reinstalarse en el campo político argentino cuando su intranscendencia (y la de todos los individuos y grupos auto-proclamados nacionalistas) era notoria. Quizás, por esa misma razón, el texto tiene una densidad intelectual y argumentativa superior a los escritos políticos anteriores al golpe de septiembre. Por lo tanto, entiendo que su estudio se vuelve interesante para conocer la evolución de los escritores de la derecha autoritaria argentina y vislumbrar como fueron evolucionando sus pensamientos y propuestas en relación con la dinámica histórica. En este sentido, adhiero a las perspectivas de la historia intelectual que consideran que un texto no es sólo un conjunto de ideas, enunciados y contenidos, ni un dispositivo para producir enunciados, sino que también implica, él mismo, una intervención concreta sobre la realidad. De tal modo, el contexto deja así de aparecer como una mera referencia externa a los discursos para pasar a formar parte integral de su sentido. Al respecto puede verse: Palti, Elías J.: "La historia intelectual latinoamericana y el malestar de nuestro tiempo", en Anuario del IEHS 18, Tandil, en prensa.

34 Lugones, Leopoldo: El Estado equitativo (Ensayo sobre la realidad argentina), La Editora Argentina, Buenos Aires, 1932, pág. 9. También sostenía que "la libertad de producción y de comercio plantea un conflicto fundamental con el deber gubernativo de garantir la prosperidad común (...) el orden económico está dentro del orden público", Lugones: El Estado equitativo, pág. 10. 
económicos que afectaban al país eran producto del papel dominante del comercio sobre la producción. Por lo tanto, invirtiendo los términos, reclamaba la preeminencia de la producción sobre el comercio, estipulaba que el Estado debía reorganizarse con el designio de autoabastecerse utilizando, intensiva y preferentemente, los recursos propios hasta convertir al mercado interno en el fundamento de la prosperidad nacional. ${ }^{35}$ De tal modo, la producción agrícola ganadera debía reorganizarse y liberarse de la dependencia que la ataba a las potencias, particularmente a Gran Bretaña, dando importancia despótica a los intermediarios del comercio exterior y de las industrias de la carne y los cereales. La desunión de los productores nacionales y un "individualismo grosero" eran los elementos que volvían posible la "situación colonial", que implicaba, entre otras cuestiones, la fijación de precios inconvenientes para los productores nacionales y la utilización de todo tipo de obstáculos morales y materiales para impedir el desarrollo nacional independiente. La producción argentina ejercería el gobierno económico del país, arrebatándoselo al "comercio extranjero de Buenos Aires". Señalaba que "la colonia librecambista va a convertirse en la gran nación de bastarse y protegerse, de acuerdo con la evolución impuesta a todos por la irrefragable necesidad". ${ }^{36}$

$\mathrm{Al}$ momento de señalar las medidas económicas y financieras concretas que debía aplicar el Estado revolucionario heredero de los postulados de septiembre, comenzaba con un previsible reclamo de abaratamiento de los costos de la política, pues el gobierno representativo emergente del sufragio universal era innecesariamente costoso, fundamentalmente por su tendencia a la burocratización y por su inclinación a los sobornos como herramienta clientelística. Asimismo, avanzaba con otra serie de medidas perentorias: demandaba reducir todos los gravámenes de la propiedad inmobiliaria a un sólo impuesto progresivo, proponía también crear un arancel gradual a la renta y a los réditos percibidos por ausentismo y por capitales colocados fuera del país. De igual forma, procuraba que se decretase la "exención estimuladora" de la pequeña propiedad, para que esos recursos se destinaran a la producción o a vivienda propia, lo mismo que del capital formado por el ahorro o invertido en el comercio exterior, en las industrias de la construcción y de base. Estas industrias tanto como la minería debían ser impulsadas y organizadas desde el Estado. Finalmente,

35 Lugones: El Estado equitativo, pág. 31.

36 Lugones: El Estado equitativo, pág. 63. 
proponía renovar a largo plazo, o decretar la moratoria de la deuda externa, evitar la emisión excesiva de moneda, suspender las ejecuciones hipotecarias, reducir el presupuesto en general (sobre todo en educación y obras públicas) pero aumentar el destinado a las fuerzas armadas y a la industria bélica. $^{37}$

Haciendo un fuerte hincapié en el productivismo, en tanto concepto forjado idealmente para superar el concepto marxista de lucha de clases, Lugones proponía un proyecto económico que, sin hostigar explícitamente al trabajo, fuera lucrativo para el capital. Su programa de "Estado orgánico" ampliaba los objetivos de la iniciativa privada "nacional" y la propiciaba como complementaria con el desarrollo de una economía pública, es decir dedicada al engrandecimiento de la nación y del tan anunciado bienestar general.

El corporativismo ${ }^{38}$ "lugoniano" implicaba una comunidad de intereses tendente a generar una unidad armónica. Sin embargo, como era habitual en sus proclamas, no se adentraba en explicaciones más concretas y análisis más sustanciosos. Sí resultaba evidente que el Estado debía ser el articulador de los diferentes sectores de la producción, asumiendo la función de reestructurador del sistema productivo con claro acento en la industrialización, aunque sin desconocer la importancia que revestía para la economía argentina la actividad agropecuaria. Es decir, la industria era concebida como un quehacer cardinal, pero que necesariamente debía estar integrada con las otras empresas, ya fuera la de los productores primarios o el comercio. Proponía una concentración y racionalización de la economía desde una perspectiva llamada nacionalista, en la cual, indefectiblemente, el centro de decisión debía residir en el Estado argentino, tanto para la organización como para la obtención y distribución de los beneficios.

De tal manera, alegaba que la práctica de regulación colectiva supervisada por el Estado debía actuar positivamente frente a la atomización y

37 Lugones: El Estado equitativo, págs. 104 a 110.

38 Los debates en torno a propuestas corporativas cruzaban a todo el ámbito de la derecha argentina y se venían desarrollando desde bastante tiempo atrás (involucrando también a algunos promotores del liberal conservadurismo). Tal el caso de Carlos Ibarguren, referente de la derecha autoritaria de las décadas de 1920 y 1930, quién siendo ministro de Justicia e Instrucción Pública de Sáenz Peña había elaborado algunos proyectos de evidente tendencias corporativas. No me es posible, por razones de espacio, extenderme sobre esta cuestión, pero no puedo dejar de mencionar que también en este aspecto el acuerdo era bastante superficial, ya que los proyectos (con mayor o menor grado de elaboración) de los intelectuales autoritarios diferían considerablemente, ya que mientras algunos apostaban a un corporativismo sustentado en la reforma social, otros reclamaban un corporativismo esencialmente político, sin que faltaran los que apostaban a soluciones híbridas o parciales. 
la imprevisibilidad de las economías de mercado y a la ineficiencia burocrática de los sistemas centralizados comunistas. ${ }^{39}$ Esta retórica de "tercera posición" en definitiva no disimulaba que el poder económico no cambiaba de manos, sino que solamente se disponía de una manera diferente y con una intervención explícita del Estado..$^{40}$ No se trataba de aspirar a la abolición de las jerarquías sociales, sino que buscaba implantar una forma de modernización de la economía que mantuviera la empresa privada, pero priorizara la eficiencia y apelara al control público de algunos sectores de la economía como parte del proyecto productivista bajo el impulso y control estatal. ${ }^{41}$ Evidentemente, esto no era en absoluto inaudito ni original, ya que el propio capitalismo estaba abriéndose paulatinamente a un sistema de mercado mucho más imperfecto e intervenido que lo que estipulaba su doctrina. ${ }^{42}$

Además, Lugones prestó atención a la crisis internacional ${ }^{43}$ (y sus manifestaciones en Argentina) a la que consideraba resultante de un sistema que se acababa: el liberalismo internacionalista o humanitario. ${ }^{44}$ Una inestabilidad que se expresaba en el plano económico, pero también en la política y la cultura. El corporativismo era presentado, entonces, como la

39 Para analizar los diálogos del proyecto "lugoniano" con la práctica económica fascista puede verse el ya clásico libro de Sarti, Roland: Fascismo y burguesía industrial, Italia 1914-1940. Un estudio del poder privado bajo el fascismo, Fontanella, Barcelona, 1973

40 Las políticas proteccionistas, por efecto de la crisis, se habían difundido por buena parte del mundo occidental. Por lo tanto, también en este punto es necesaria la cautela al tiempo de atribuirlas como una influencia exclusiva de los estados totalitarios y fascistas.

41 Mosse, George: La cultura europea del siglo XX, Ariel, Barcelona, 1997, págs. 156-157.

42 Así lo ha señalado y tempranamente: Svennilson, I.: Growth and Stagnation in the European Economy, 1954. Recuérdese asimismo que, en 1926, Keynes publicaba El final del laissez faire y reclamaba una estructuración económica alternativa. Véase Keynes, J.M.: El final del laissez faire. Ensayos en persuasión, Crítica, Madrid, 1988, y Teoría general de la ocupación, el interés y el dinero, FCE, México, 1980.

$43 \mathrm{Al}$ respecto entendía que la gran depresión se debía a la sobreproducción mundial, es decir, que era resultado de un exceso de oferta ante una demanda disminuida no por el aumento de las tarifas aduaneras, sino por el incremento de la producción fabril y agraria que efectuaban muchas naciones con el objeto de bastarse, realizándolo "algunas como Italia, en condiciones sorprendentes". Al problema de una producción depreciada en el mercado internacional, se sumaba el alto nivel de salarios y las cortas jornadas laborales impuestas por exigencia gremial.

44 Es interesante tener en cuenta que, como los otros referentes de la derecha intelectual, las menciones al liberalismo (aun las más críticas) se hacían a través de un discurso donde el liberalismo iba siempre adjetivado, en este caso habla de un liberalismo internacional o humanitario. Como ya he señalado en otros trabajos, es necesario reflexionar sobre el carácter antiliberal de esta tendencia y preguntarse si estos intelectuales (con sus diferencias y tensiones) no cuestionaban, más que al liberalismo en su conjunto, la forma que el liberalismo había asumido. En ese sentido, no pocas veces se mostraron condenatorios con camino desviado y erróneo que el sistema había seguido y que había desvalorizado las virtudes originales. 
única alternativa posible y eficaz de hacerle frente al desbarajuste provocado por la crisis, tanto a nivel local como en otros países del mundo.

Como ideólogo y poeta de lo nacional, proponía tender a la reconcentración nacional, caracterizada por la preeminencia del productor agrario, el militar y el artista, es decir, "los elementos más genuinos" del país. En una llamativa articulación social basada en órdenes que recuerdan el modelo tripartito medieval: "Así, en tríada que dijérase religiosa, el sembrador, el defensor y el glorificador".

El Estado corporativo habría de constituirse como entidad representativa de la producción y el trabajo organizados al efecto en gremios "responsables", que contuvieran a la población nativa y naturalizada. La organización funcional estaba obligada a ser reflejo de la realidad del país, y por lo tanto otorgar la representación mayoritaria a los sectores agrarios ya que "constituimos una república rural". ${ }^{45}$ El nuevo Estado, por definición, funcionaría sin la existencia de políticos profesionales y sin el régimen de partidos conocidos hasta el momento. ${ }^{46} \mathrm{El}$ Estado orgánico y equitativo pretendía mantener la estructura de clases, pero fundiendo a la población en un todo mediante la ideología del "Volk", ${ }^{47}$ a través de una historia o un sentimiento común. Este espíritu debía expresarse mediante una sociedad jerarquizada y a través de un caudillo. La "aristocracia del espíritu" debía asumir la expresión de la hidalguía compartida de la nación, conducir al pueblo al desarrollo pleno de su personalidad auténtica.

El Estado era pensado, a la sazón, como un instrumento militante que necesariamente debía transformar el gobierno en mando, mediante una ofensiva general, "reaccionaria pero no conservadora". ${ }^{48}$ Se trataba de impulsar un Estado interventor en todos los órdenes que sostuviera una perspectiva "nacional" y atacara la "indiferencia cosmopolita", reorganizando "la Nación sobre la realidad presente y la experiencia propia, con abstracción de ideologías ecuménicas". ${ }^{49}$

Es interesante señalar que Lugones decía retomar la concepción romana de la Patria que Maquiavelo había reestablecido "tras mil años de confusión medieval" y afirmaba que no existía conflicto esencial, sino con-

45 En este libro, editado en 1932, Lugones puso un mayor énfasis reivindicativo en los sectores rurales. Si bien no había abandonado sus planteos industrialistas, y probablemente por efecto de la crisis, estos quedaban relegados en relación a las referencias a los productores agrícolas ganaderos.

46 Lugones: El Estado equitativo..., págs. 38-39.

47 Mosse: La cultura europea..., pág. 147.

48 Lugones: El Estado equitativo..., pág. 12.

49 Lugones: El Estado equitativo..., pág. 12. 
tradicciones circunstanciales entre la entidad metafísica que representaba Dios y la entidad moral que encarnaba la religión de su culto, con el hecho político que constituía la patria.

Así, asumiéndose como un realista empírico y pragmático político, sostenía que no había que teorizar acerca de los principios del Estado, ya que este no resultaba moral ni inmoral, sino amoral, agnóstico y oportunista o empírico. ${ }^{50}$ El Estado "lugoniano" era una entidad estrictamente política y económica que podía reconocer o no una religión "por tradición, conveniencia o cualquier otro motivo". Sin embargo, el Estado debía velar indefectiblemente por la moral, la consolidación de la familia, entre otras cuestiones. Pero esto no debía entenderse como una toma de posición ética del Estado, sino como un castigo a las transgresiones en resguardo del orden público. ${ }^{51}$

El Estado, a diferencia de la religión y la filosofía, no debía buscar la verdad, al menos no la misma verdad, sino aquella que derivase en el bienestar común y fuera resultado de la conformidad entre la mente y el conocimiento. Un postulado fisiológico, la necesidad, era el motor indiscutible de la acción y las formas políticas que caracterizarían al Estado. Su fin era el bienestar común, su misión para alcanzarlo radicaba en la imposición de la armonía social. Estas eran las ventajas del pragmatismo, a todas luces, según Lugones, indudablemente más efectivas que los estrictos caminos del principismo.

Toda la argumentación iba a favor del pragmatismo y en contra de aquellas tendencias que partían de un ideal mayor, y que constituían a sus principios en proyectos y en identidad misma. El principismo, entendía Lugones, se convertía así, en muchos casos, en un obstáculo, o al menos en un elemento retardatario, para la realización del bienestar común de una nación poderosa, único objetivo de la acción política fundado en el criterio de la "razón de Estado". Esos preceptos, esas máximas, que consideraba constitutivas de las ideologías de izquierda, aunque también del liberalismo, eran percibidas por Lugones como manifestaciones de la cobardía, de la falta del heroísmo viril que él le reclamaba a los hombres y a los políticos en particular. Es decir, el realismo político, entendido como la falta de restricciones morales y éticas y la apelación a todo lo que pudiera hacer posible el proyecto anhelado, era postulado por Lugones como el más cla-

50 Lugones: El Estado equitativo..., pág. 13-14.

51 Lugones: El Estado equitativo..., pág. 14-15. 
ro sinónimo de valentía y de osadía estratégica. El Estado equitativo, por tanto, debía satisfacer "lo posible, no lo ideal". ${ }^{52}$

En ese sentido, entendía que la reorganización política del Estado, en concordancia con la organización económica realmente existente, era indispensable para el logro del objetivo propuesto: "Si el gobierno de la Nación ha de representar su entidad política (...); su entidad económica formada por la producción, el trabajo y la riqueza nacionales, y su entidad potencial o soberanía en el mundo: ni el pueblo elector debe confundirse con la población habitante; ni carecer la entidad económica de representación proporcional a su importancia". ${ }^{53}$

La clasificación de los electores se basaba en el rendimiento útil en cualquier trabajo personal y regular, de modo que "no pueda ser elector ningún parásito social, desde el vago de suburbio hasta el haragán de club que vive de la renta producida por el esfuerzo ajeno, y desde el jornalero ocasional hasta los inútiles del doctorado decorativo". ${ }^{54}$

La disposición de los ciudadanos productores por oficios, profesiones y carreras, ponía en manos de cada uno de esos grupos su propio censo electoral, así como la responsabilidad ante el Estado por los electores que acreditaba. Al Estado correspondía la fiscalización consiguiente, desde aquel censo primario hasta los juicios de todas las asociaciones representativas de los oficios, profesiones y carreras. El reconocimiento legal se obtendría mediante condiciones análogas a las que requería el reconocimiento de la personería. Organizada en esta forma la representación del país, todos los intereses y elementos útiles de la cultura y de la producción tendrían directamente la suya en la Cámara de Diputados nacionales y en las legislaturas de provincia. Aunque el senado federal debía organizarse de una manera muy similar a la existente..$^{55}$

De esa manera, declamaba Lugones, se terminaría con la "facciosa, extranjera y antirrepublicana división de clases" y, obviamente quedaban excluidos, por falta de motivo, los partidos históricos, cuya responsabilidad, decía, era prácticamente imposible de definir, tanto como la de los políticos profesionales. Por el contrario, la corporación permanente y definida por su actividad peculiar, permitía establecer ante la justicia responsa-

52 Lugones: El Estado equitativo..., pág. 80.

53 Lugones: El Estado equitativo..., pág. 71.

54 Lugones: El Estado equitativo..., pág. 72.

55 Lugones: El Estado equitativo..., págs. 103-104. 
bilidades y derechos electorales con plena garantía de resguardo, como sucedía en lo civil y en lo criminal..$^{56}$

Como ya he explicitado, Lugones entendía que en primer término debían ubicarse los productores agrarios, clasificados como tales y no como patrones y dependientes, pues era lo que correspondía a la realidad de una república rural. Se dispondrían luego los sectores del comercio, después la industria y finalmente las profesiones liberales.

Según entiendo, lo más interesante en la perspectiva "lugoniana" posterior al golpe de Estado, era el cuestionamiento del concepto de soberanía popular. Esa crítica partía de la descalificación de las teorías de Locke y Rousseau, aunque sin analizar en profundidad el pensamiento de estos autores, hallaba que todo el andamiaje de la política de la modernidad era el promotor de los desbordes sociales. Asimismo, argumentaba que la principal razón de su inaplicabilidad a la realidad argentina residía, a diferencia de los países anglosajones, en la ausencia del poder disciplinador de la religión. ${ }^{57}$ De tal modo, la soberanía popular tenía que quedar limitada, sujeta a las determinaciones de la soberanía de la nación: "toda libertad contraria a la nación es delito". ${ }^{58}$

La soberanía de la nación debía expresarse a través de un Estado que procurara, impusiera y defendiera el orden, "es decir la equidad", de tal modo que ese Estado, debía asumir un carácter defensivo que implicaba, asimismo, una indiferencia ante la libertad, "que no le incumbe, porque ella es facultad personal y no materia de Estado". ${ }^{59}$

La libertad, en el esquema "lugoniano", estaba obligada a subordinarse al orden, tanto como al individuo correspondía someterse a la sociedad, ya que el individuo nacía en el orden. Es decir, obligado ante la sociedad. Como puede observarse, Lugones expresaba una ruptura categórica y acentuada con las bases doctrinales más puras del liberalismo. "El gobierno puede o no representar al pueblo", pero siempre debía representar a la nación. Esa era, para el poeta militarista, la gran tarea y la "gran victoria" de la revolución de septiembre: "El Estado nada tiene que hacer con la

56 Lugones: Política Revolucionaria..., pág. 104.

57 Lugones: Política Revolucionaria..., pág. 56. Como puede advertirse, estaba expresando así una reconsideración del papel de la religión —a la que anteriormente había considerado como el mayor instrumento de sumisión y retraso presente en el mundo occidental- y se acercaba a los otros referentes de la derecha autoritaria naciente, al encontrar en ella un interesante instrumento de obediencia, disciplina y control social

58 Lugones: Política Revolucionaria..., pág. 56.

59 Lugones: Política Revolucionaria..., pág. 57. 
libertad. Su objeto es el orden. Cuando el ejercicio de la libertad perjudica al conjunto o a tercero, es ese perjuicio y no la libertad lo que le compete (...) la libertad está dentro del orden, como el individuo dentro de la sociedad. El individuo nace en el orden, es decir obligado ante la sociedad, como nace libre en su conciencia. El sostén de aquella obligación es lo que concierne al estado". ${ }^{60}$

La nación, en la obra de Lugones, no fue expresada a través de un concepto definido, ni delimitado. Sin embargo, resulta posible inferir que era entendida como una situación de orden, una estructuración jerárquica, disciplinada y altamente productiva. La sociedad resultaba, entonces, como un colectivo sin otras aspiraciones que dar forma y grandeza a ese concepto trascendente y superior.

Para lograr la grandeza de la nación, la sociedad debía organizarse bajo el mando de una guía fuerte, ya que no "hay acción colectiva sin jefe" ", ${ }^{11}$ articulándose como un conglomerado jerarquizado política y económicamente. La igualdad política, decía, si bien se la miraba era una forma de comunismo. De este modo, la nación en sí misma obligaba a reconstruir el colectivo, sobre nuevas bases, con nuevas normas, para alcanzar las características de la comunidad anhelada, disciplinada y clasificada.

Así, reclamaba para su concepción de la nación el status de un mito, de una construcción ideológica que se asentaba en fundamentos subjetivos y emocionales. La nación aparecía como un destino de grandeza, una fe que reclamaba de la valiente obediencia de sus habitantes.

Las potencialidades evidenciadas a lo largo de la historia eran las que señalaban ese destino de grandeza, pero no sólo la historia efectivamente transcurrida, sino, especialmente, la reconstrucción, también mítica, de esa historia, la valoración de esas supuestas potencialidades argentinas. Es decir, que ese concepto rompía con la idea organicista y romántica de la nación. Ya no se trataba de una realidad precedente que evolucionaba, sino que era un espíritu, aquel mito superior, aquella atmósfera de orden, de esplendor y de gloria. Henri Lefebvre ha analizado esta cuestión como la emergencia de una nueva concepción del mundo que se articulaba con una nueva percepción de la realidad, donde el mito (aunque podría pensarse como una idea falsa) no contradecía la verdad. ${ }^{62} \mathrm{El}$ mito de "la patria fuer-

60 Lugones: Política Revolucionaria..., pág. 62.

61 Lugones: Política Revolucionaria..., pág. 32.

62 Lefebvre, Henry: Le nationalisme contre les nations, Méridiens Klincksieck, París, 1988, pág. 151. 
te", que tantas veces y con tanta vehemencia proclamó Lugones, se convertía en realidad, ya que era el instrumento, la fuerza histórica efectiva para poder cumplirlo. ${ }^{63}$ El mito debía servir de estímulo a la voluntad de acción, para la homogeneización de la sociedad y la utilización cabal de sus energías. El mito debía permitir canalizar la participación de una sociedad de masas en un contexto de orden y disciplina (el mismo objetivo se buscaba en el plano material con la estructuración corporativa). En definitiva, buscaba estipular una forma de intervención de las masas que no escapara al control social.

La nación "lugoniana" no estaba habitada por individuos, sino por una sociedad ordenada, estructurada y subordinada, sin más derechos políticos que los de pertenecer a esa nación y desarrollar una actividad productiva. Es más, los derechos no eran otra cosa que deberes del ciudadano. ${ }^{64} \mathrm{El}$ derecho de ciudadanía era excluyente de extranjeros e improductivos, pero sostenía que no establecía diferencias entre patrones y asalariados (tampoco buscaba transformar esa relación en la esfera productiva y distributiva), por lo cual su proyecto de nación era pluriclasista, aunque no igualitario, en sus propias palabras era "equitativo".

En más de un aspecto Lugones recuperaba algunos puntos del debate surgido a fines del siglo XIX, al manifestar una concepción esencialista, excluyente y defensiva de la nación, cuya existencia se afirmaba más allá de las formalidades legales. ${ }^{65}$ Estas expresiones evidenciaban, según sostiene Lilia Ana Bertoni, un temprano quiebre de las perspectivas más indiscutiblemente liberales y cosmopolitas de la nación, producto de las transformaciones que se estaban produciendo, en particular, el masivo arribo de contingentes inmigratorios. Paralelamente, comenzaba a surgir una disputa en torno al espacio y la autonomía atribuidos a los derechos de los ciudadanos en relación a los atribuidos a la defensa del interés nacional. ${ }^{66}$

La cuestión de los derechos de los inmigrantes fue importante y de largo alcance, en el pensamiento nacional argentino. Comenzada la década de 1930, Lugones pretendía resolverla revisando todo aquello que se cons-

63 Algunas de estas consideraciones resultaron de la lectura del sugerente trabajo de Palti, Elías: "Nación. El enfoque genealógico de la nación y sus descontentos. El dilema Hobsbawmiano", en Palti, Elías: Aporías. Tiempo, Modernidad, Historia, Sujeto, Nación, Ley, Alianza Editorial, Madrid Buenos Aires, 2001, págs. 209 a 212.

64 Lugones: El Estado equitativo..., pág. 14.

65 Bertoni, Lilia Ana: Patriotas, cosmopolitas y nacionalistas. La construcción de la nacionalidad argentina a fines del siglo XIX, FCE, Buenos Aires, 2001.

66 Bertoni: Patriotas..., pág. 312. 
tituyera como un privilegio del extranjero con respecto al ciudadano nativo o naturalizado. Sostenía que era necesario que la ciudadanía fuera una ventaja, implicara beneficios, y por lo tanto promoviera a los inmigrantes a adoptar la nacionalidad argentina. Ya que, según Lugones, "la excesiva liberalidad" de las leyes argentinas había atentado contra ese proceso deseable y políticamente conveniente, ${ }^{67}$ "el extranjerismo es la peor debilidad, no sólo porque constituye un estado de alma indiferente, cuando no hostil a la nación (...) sino porque alberga al enemigo más pernicioso en la persona del huésped disconforme o agitador". ${ }^{68}$

Siendo la nación la entidad política aglutinante y la herramienta indispensable para alcanzar la unidad y estructuración del cuerpo social, era indispensable que todos los habitantes de la nación se subordinaran a ella, se identificaran con ella y en tanto ciudadanos productores trabajaran por su expansión. Los extranjeros que escaparan a esa ordenación se encontrarían siempre proclives a la anarquía, al desorden y la indisciplina. Por lo tanto, sólo los ciudadanos debían tener representación y capacidad para ejercerla. Aquellos extranjeros que no se nacionalizaran, no lograrían los beneficios de la ciudadanía y se hallarían "tan sólo protegidos por la ley". ${ }^{69}$ Lugones entendía que la Constitución argentina, ese "poema ideológico del extranjerismo", otorgaba a la condición de extranjero superioridad sobre la ciudadanía. Ello explicaba, para Lugones, la escasa naturalización y, fundamentalmente, la subversiva y desintegradora actividad política de los extranjeros: "En ninguna parte es tan insolente la crítica extranjera (...) $\mathrm{ni}$ tan grande el número de extranjeros delincuentes y alienados. Son muchos los extranjeros que viven en permanente estado de subversión y menosprecio contra el país". ${ }^{70}$

La preocupación de Lugones era particularmente notable en cuanto que muchos extranjeros ejercían influencias políticas y educaban a sus hijos en la misma animosidad contra la nación. Por lo tanto, las pautas políticas al respecto debían ser férreas y tomadas sin demoras. El estímulo a la naturalización tenía que comprometer una desigualdad ventajosa para la ciudadanía, un privilegio positivo que no permitiera, por ejemplo, que los extranjeros accedieran a la propiedad de la tierra y desarrollaran cualquier tipo de accionar político. Así, continuaba diciendo, tanto como en los

67 Lugones: Política Revolucionaria..., pág. 48.

68 Lugones: Política Revolucionaria..., pág. 57.

69 Lugones: El Estado equitativo..., págs. 48-49.

70 Lugones: El Estado equitativo..., pág. 55. 
Estados Unidos de América los extranjeros buscarían ser naturalizados con plena satisfacción.

En mi opinión, Lugones podría ser considerado un heredero, considerablemente radicalizado, de la concepción culturalista, o cultural esencialista, que encarnaba un pensamiento defensivo, excluyente y nacionalista opuesto a la tradición cosmopolita que proponía un contrato de incorporación voluntaria y manifiestamente tolerante. Su perspectiva de nación era excluyente y expansiva, por lo cual necesitaba de un Estado fuerte, capaz de excluir a los insubordinados e indeseables, de incorporar a los productores ordenados, y en lo posible de propagarse más allá de sus fronteras, es decir llevar adelante una política de expansión territorial o dominio imperialista. Hablar de nación implicaba, para Lugones, hablar de unidad (una unidad que en el caso argentino se expresaba en menos elementos que los deseables), que se enfrentaba a los principios universales de la libertad y la justicia. Esta definición, además, iba asociada a la idea de patriotismo y conllevaba una valoración, un significado moral en tanto que entrañaba una cultura y un objetivo esencial para el desarrollo que toda la sociedad debía perseguir. Esta configuración iba asociada a un sentimiento de superioridad con respecto a todos los diferentes (en toda la amplitud de esa vasta definición), que necesitaba recuperar algún elemento de orgullo sobre el que establecer esa preponderancia, algo de lo que pudieran vanagloriarse los argentinos. Ese orgullo - que siempre corre el riesgo de volverse un nacionalismo arrogante y belicoso, como ha señalado Richard Rorty - ${ }^{71}$ asumió en Lugones la forma de una promesa de futuro.

Ahora bien, la continuidad con algunas corrientes de opinión de fines del siglo XIX se dio también en otro plano. Con su militarismo exacerbado, y en un contexto social relativamente alentador para ese tipo de posturas, Lugones remarcaba la importancia de la formación y disciplina de las fuerzas armadas, la conscripción obligatoria, la práctica de gimnasia y tiro para la formación de jóvenes sanos y fuertes, es decir viriles. Como en la década de 1890, estas cuestiones eran vistas como estrechamente ligadas con la construcción de la nacionalidad, y la afirmación de una nación potencia. ${ }^{72}$ Lugones sostenía que a la opinión se la formaba con actos enér-

71 Rorty, Richard: "La academia antipatriótica", en AAVV: Cosmopolitas o patriotas, FCE, Buenos Aires, 1997, pág. 32.

72 Al respecto puede verse el trabajo de Bertoni: Patriotas..., pág. 213 y ss., y Ferrari, Gustavo: "La Argentina y sus vecinos" en Ferrari, Gustavo, y Gallo, Ezequiel: La Argentina del ochenta al centenario, Sudamericana, Buenos Aires, 1980. 
gicos, y desde esa contingencia reclamaba la instrucción militar en las escuelas primarias y normales de varones, tanto como en los colegios nacionales, bajo la dirección de los oficiales del Ejército y en reemplazo de los ejercicios físicos propuestos por los planes de estudios vigentes, a los que consideraba "una farsa que sólo motiva sueldos inútiles". ${ }^{73}$

De tal modo que la preparación física y también militar de los ciudadanos fue concebida, tanto a fines del siglo XIX como en la década de 1930, como una forma de fomentar el patriotismo y la grandeza de la nación. Lugones buscaba exacerbar la conciencia de la obediencia civil, subordinarla a la mentalidad y a la institución militar, lo que implicaba rechazar aquel dogma básico y absoluto de las sociedades liberal-democráticas que establecían la preeminencia de la sociedad civil como dueña de la soberanía. ${ }^{74}$ Por el contrario, el militarismo de Lugones reivindicaba la preponderancia o predominio de los grupos militares, en tanto que implicaban una moral que tenía como finalidad la exaltación de la patria y que, mediante la valentía y la virilidad, podía - de hecho consideraba que era la única institución capacitada para - ejercer primacía en la organización socio-política. La institución militar, fuertemente jerarquizada, resaltaba por contraste la democratización ciudadana y otorgaba argumentos para rechazar ese producto del individualismo.

Lugones se desplegaba como admirador de la función de los militares, de su capacidad de aplicación de la violencia y de su estructuración institucional. Desde esa representación, la organización militar implicaba tanto una organización política como una relación de poder, y por ello pretendía asignar sus objetivos y sus valores al conjunto social. La glorificación de esa conducta y de esa moral comprendía el culto a la guerra, a la fuerza, a la disciplina y a la masculinidad; exigía tanto una política expansionista como una vocación de influencia interior, y el crecimiento a nivel material y personal de las fuerzas armadas en detrimento de otros sectores del Estado. ${ }^{75}$ El ejército sintetizaba y defendía la esencia de la nación, monopolizaba el patriotis-

73 Lugones, Leopoldo: "Informe Confidencial al gobierno revolucionario", reproducido por García, Alicia S., y Rodríguez Molas, Ricardo: Textos y documentos. El autoritarismo y los argentinos. La hora de la espada/l (1924-1946), CEAL, Buenos Aires, 1988, pág. 56.

74 Para un análisis más profundo de este tema puede verse: Vergottini, G: "La supremacía del poder civil sobre el poder militar en las primeras constituciones liberales europeas", en Revista Española de Derecho Constitucional, N. ${ }^{\circ}$ 6, septiembre-diciembre de 1982; Smith, Louis: La democracia y el poder militar, Buenos Aires, 1965; Núñez Florencio, Rafael: Militarismo y antimilitarismo en España, (1888-1906), Consejo Superior de Investigaciones Científicas, Madrid, 1990; Seco Serrano, Carlos: Militarismo y civilismo en la España Contemporánea, Madrid, 1984.

75 Núñez Florencio: Militarismo..., págs. 16-17. 
mo, encarnaba el honor viril de la patria y, por lo tanto, debía imponerse sobre el poder civil y ejercer su función correctora. La vida política y social debía asumir un sentido militar; la sociedad tenía que incorporarse, someterse, a aquella lógica. En su caso no se trataba de un militarismo que se conformaba con imponer a las fuerzas armadas en los cargos ejecutivos, sino de un militarismo que debía teñir a la sociedad —y estructurarla a semejanza de las fuerzas armadas — con sus principios, su obediencia y su dinámica.

Como resulta evidente, para la reconstrucción de la nación argentina, para llevarla a "su verdad", Lugones entendía que era indispensable una reforma amplia y radical. Una modificación del sistema político que, según decía, el pueblo (un pueblo no definido ni caracterizado) reclamaba. Lo que la sociedad pedía con mayor urgencia, continuaba diciendo, era autoridad y administración, "orden en una palabra", pues era el verdadero afectado por la "orgía electoral demagógica" que había dejado una serie de secuelas, entre las cuales el déficit económico era sobresaliente. ${ }^{76} \mathrm{~A}$ pesar de su desprecio por las mayorías y por la soberanía popular, buscaba legitimar su propuesta con un supuesto consenso popular, y desde allí argumentó una oposición reflexiva entre legalidad y eficacia. Así sostenía que una nación mal gobernada se hallaba dentro de la ley, pero fuera de la razón y de la equidad: "lo que corresponde, entonces, es derogar o reformar la ley para no seguir perjudicando a la Nación. Esto es de mero sentido común. La razón y la equidad son anteriores y superiores a la ley: de suerte que cuando entran en conflicto ha de ceder la ley". ${ }^{77}$

En este sentido, resultaba clara su adhesión a las posturas conocidas como realismo político o realismo empírico, a las que él definía como el "arte de la política, que carece de ideología trascendental, pero que cuenta con la vida".$^{78}$ De tal modo que, de la Constitución de 1853, proponía mantener su espíritu, que era el de la grandeza de la patria, pero rechazaba enérgicamente encasillarse en su "letra inamovible" ${ }^{79}$ Por ello, para mantener aquel espíritu básico y esencial se había realizado la revolución, para terminar con el destino de sometimiento que la democracia liberal proponía a la nación. No renegaba de los principios republicanos, representativos y federales, pero los llenaba con un contenido diferente al que históricamente se les había dado. Asimismo, sostenía que la ley electoral de 1912,

76 Lugones: Política revolucionaria..., págs. 48-49.

77 Lugones: Política revolucionaria..., págs. 63.

78 Lugones: Política revolucionaria..., págs. 66.

79 Lugones: Política revolucionaria..., pág. 88. 
por su parte, había fracasado por la falta de partidos orgánicos y de hecho se había convertido en un instrumento negativo, disolvente y generador de la anarquía del liberalismo y del privilegio de clase que el socialismo pretendía trasladar de la burguesía al proletariado ${ }^{80}$ La defensa de la nación no podía subordinarse "sin criminal insensatez" al azar de las elecciones y a la paradoja de "la igualdad antinatural y anticientífica" ${ }^{81}$

Como ya he sostenido, demandaba la autonomía de las fuerzas armadas, al tiempo que anunciaba que el ejército debía convertirse en ciudadano. Pero, señalaba también que debía ser el organizador de toda la actividad nacional, pues era el único cuerpo estructurado bajo un concepto de eficacia inmediata y de disciplina indiscutida. Dicho de otro modo, impulsaba la participación de las fuerzas militares, en tanto poder gubernativo, en todas las actividades de la nación. Entendía, entonces que había que dotar al ejército de una prerrogativa de gobierno, que por su técnica específica debía gozar de cierta independencia con respecto a las otras esferas del poder, aunque subordinado al proyecto mayor de construir "la grande Argentina". Asimismo, entendía que el servicio militar, por conscripción obligatoria, transformaba a las fuerzas armadas en representación permanente del pueblo. ${ }^{82}$

La soberanía era entendida como sinónimo de "poder y de autoridad", porque la soberanía de la nación no podía quedar supeditada a la del pueblo. Sólo así se alcanzaría la "armonía perfecta", imperativa para alcanzar el bienestar común y la exaltación de la patria. La unidad de la nación, sostenía por entonces, sólo podía alcanzarse por el territorio y el idioma ya que no existía una unidad étnica que sirviera de elemento aglutinante. Y por eso mismo, se volvía indispensable constituir un gobierno, una autoridad muy fuerte, "o sea proporcionada a la endeblez del cuerpo social". ${ }^{83}$ Pero esa potestad debía contar con la activa y decisoria participación de los intelectuales, portadores de un propósito nacional y consciente y constructores del mito de lo nacional. Los pueblos tendentes a la anarquía, como Lugones caracterizaba a los argentinos, necesitaban de la guía, de la dirección de sus espíritus más destacados ${ }^{84}$ que pudieran compensar los desequilibrios socia-

80 Lugones: El Estado equitativo..., pág. 38.

81 Lugones: El Estado equitativo..., pág. 67.

82 Lugones: El Estado equitativo..., pág. 68. El ejército era indispensable para el engrandecimiento de la nación, tanto asumiendo la defensa como la imposición sobre otras naciones. Incluso sus necesidades técnicas obligaban a desarrollar una industria bélica que contribuiría así al desarrollo de las fuerzas productivas nacionales.

83 Lugones: El Estado equitativo..., pág. 75

84 Lugones: El Estado equitativo..., pág. 76. 
les, ya que eran los únicos capacitados para comprender, con el auxilio de instrumentos científicos, que la ley del progreso indefinido no era más que una falacia del liberalismo. A partir de esa celebración de los escritores y artistas, cuya obra —esencial— era la "construcción misma de la patria", ${ }^{85}$ argumentaba que las sociedades se regían por la "ley del péndulo", que llevaba de la acción a la reacción. De tal suerte que la oscilación extrema hacia el liberalismo señalaba el comienzo de la reacción autoritaria. ${ }^{86}$

Esa intransigencia se convertía, en los discursos más radicalizados y provocadores, en rechazo al racionalismo, "el despótico absolutismo de la razón", pues siendo éste una facultad esencialmente crítica, su predominio resultaba un elemento desintegrador, pesimista y negativo y, obviamente, de escasa capacidad de acomodo a las necesidades del momento.$^{87}$ De esta forma reafirmaba que el Estado no debía tener doctrina, escuela ni filosofía, "en una palabra prejuicio interruptor de su objeto que es el sostén de un orden viviente. El estadista, pues, carece de principios. Tiene un único fin, que es la grandeza de la Patria. En él consisten su justificación y su gloria". ${ }^{88}$

Pierre Rosanvallon ${ }^{89}$ sostiene que, para la modernidad, la igualdad frente a la urna electoral fue la primera condición de la democracia, la forma más elemental de la igualdad, la base más indiscutible del derecho. Por lo tanto, y como es lógico, para un pensador contrario a la democracia y a la igualdad, la universalidad del voto no reviste carácter de derecho. Su cuestionamiento, el rechazo del sistema electoral, pero también del sistema político que lo hizo posible, ocupó el centro de sus planteos disruptivos. En torno a esa descalificación articuló Lugones su proyecto político, su pretendida reorganización social, en fin, sus anhelos intelectuales y políticos. Dicho en otras palabras, su crítica a la democracia igualitaria en términos políticos procuraba deslegitimar, socavar, la consagración del individuo, y por el contrario señalaba la emergencia de un Estado omnipresente y especialmente intervencionista. Para él los hombres alcanzaban su calidad de ciudadanos en tanto parte de la nación, en la cual los lazos sociales serían resultado del lugar ocupado por cada uno en un todo organizado, fundado y sostenido por una creencia colectiva de grandeza futura. Sin embargo, no puedo dejar de advertir que en esta argumentación, Lugones acentuaba su

85 Lugones: El Estado equitativo..., pág. 76.

86 Lugones: El Estado equitativo..., págs. 9 a 11.

87 Lugones: El Estado equitativo..., pág. 21.

88 Lugones: El Estado equitativo..., pág. 80.

89 Rosanvallón, Pierre: La consagración del ciudadano. Historia del sufragio universal en Francia, Instituto Mora, México, 1999. 
crítica a la inadecuación de los medios políticos del liberalismo, mucho más que a la naturaleza de los fines buscados. ${ }^{90}$

Para Lugones, el pueblo cobraba vida en el cuerpo, en la superación del individuo, en la anulación del sujeto. Se trataba de un ciudadano productor acorde con la idea de nación preestablecida, ese cuerpo social productivo. Es decir, el trabajo y la estructuración funcional ligaba al ciudadano con el Estado, pero en ese lazo, en ese vínculo, era donde los hombres alcanzaban la ciudadanía. La soberanía dejaba de estar en manos del pueblo, en tanto organización colectiva y voluntaria de los individuos, para residir en esa situación de orden y grandeza. La soberanía prevalecía largamente sobre la figura del ciudadano y se ubicaba en ese mito fundador. El pueblo no se identificaba con la nación, sino que debía articularse como un cuerpo subordinado a ella, siempre determinado. La sociedad debía organizarse, subalternamente, en torno a un elemento rector y disciplinante.

\section{Algunas primeras conclusiones sobre Lugones y su representación del Estado y la sociedad}

Como en casi todos los pensamientos más característicos de la modernidad, los conceptos de sociedad y Estado fueron entendidos por Lugones como complementarios, pero en continua y profunda tensión, a menos que una dimensión de orden los abarcara y definiera desde una nueva perspectiva. En ese sentido, el pensamiento "lugoniano" expresaba una reacción ante los principios fundamentales de aquella concepción moderna. Lugones limitaba, con un discurso muy disruptivo y provocador, la igualdad jurídica de todos los hombres y rechazaba la noción de individuo como unidad elemental de la sociedad. Lo consideraba, por lo tanto, como irremediablemente subordinado a su comunidad, la cual debía conformarse por lazos orgánicos.

Asimismo, a diferencia del pensamiento del Antiguo Régimen, la estructuración social no estaría regida, ni determinada, por connotaciones metafísicas o sobrenaturales. La secularización del pensamiento siempre fue una constante en el pensamiento "lugoniano", incluso en sus años finales, cuando asume y defiende el capital disciplinador de la religión.

90 Albert Hirschman señala que esto es una constante del pensamiento reaccionario, ya que por su pragmatismo está siempre predispuesto a observar los medios políticos en detalle. Hirschman, Albert: Deux Siècles de rhétorique réactionaire, Fayard, Paris, 1991. 
Lugones sostenía que la autonomía del individuo sólo implicaba dejar liberado el camino a los impulsos, deseos y pasiones de manera desenfrenada, y ello era lo mismo que admitir la desintegración de la sociedad y de la nación. Suponía, también, que daba legitimidad a la lucha de todos contra todos. Así, los hombres, en la perspectiva "lugoniana", debían perder su soberanía en nombre de una soberanía nacional superior. A cambio de ello, el Estado sería el encargado de velar por el bienestar común y la expansión de la nación.

Por su concepto de disciplina, su culto a la fuerza y a la virilidad, tanto como por su capacidad administrativa, los militares eran considerados por Lugones como la mano ejecutora indispensable. ${ }^{91}$ Pero, resulta evidente que no dejaba descansar la totalidad de las esferas estatales en los militares, sino que ellos debían abocarse a la instancia práctica, la dedicada a la acción y a la ejecución: la gestión pública y la imposición del orden. Por encima de ese rol activo debía, necesariamente, asentarse en una instancia superior y reflexiva que estaría, sin otra alternativa, encarnada y desarrollada por los intelectuales.

Evidentemente, Lugones no diferenciaba entre Estado propiamente dicho y administración. Por el contrario, ambas instancias definían y conformaban al Estado, aunque se tratara de ámbitos jerarquizados, pero también complementarios.

Esa esfera de pensamiento y deliberación, que sólo podían asumir los intelectuales, era la encargada de elaborar los fundamentos del orden social, de encauzar la conducta colectiva.

Como creo que resulta claro, el Estado no era entendido por Lugones como una instancia dedicada a recoger y sistematizar las representaciones de la sociedad, sino que por el contrario era una elaboración hecha desde el Estado que debía imponerse a la sociedad. El Estado era un factor actuante, productor de representaciones y de significaciones que en muchos casos debían estar destinadas a transformar las propias representaciones, aspiraciones y la voluntad de la sociedad.

Los intelectuales, señalaba, no necesitaban involucrarse en funciones administrativas $^{92}$ para imponer su dominio. Pero, para que su función fuera

91 Lugones: Política Revolucionaria..., pág.7. En este sentido, el militarismo era considerado fundante de la sociedad nueva y cobraba una dimensión decididamente más importante que en el resto de los intelectuales que conspiraron contra la democracia yrigoyenista.

92 En todo caso, los intelectuales que se ocuparan de cuestiones de la administración serían aquellos formados especialmente para ello. En ese sentido, cabe recordar que Lugones señalaba que la Universidad, en tanto formadora de los técnicos necesarios, debía ser considerada un poder del Estado. 
todo lo determinante que debía ser, había que encarar la reforma radical de las estructuras y formas del Estado. Reorganizando el Estado se estructuraba de manera directa la sociedad bajo los parámetros del orden y la disciplina. Un orden que no se consensuaba sino que se imponía, pero un orden que también era el objeto y razón de ser de un Estado.

Se trataba de una propuesta que Lugones colocaba por encima de la política, inspirada en un objetivo de orden superior como era el engrandecimiento de la nación. En esa búsqueda reestructurante hacía fuerte hincapié en la reforma del sistema de representación. Planteaba, así, una organización corporativa, llamada "representación funcional", ${ }^{33}$ que sólo sería excluyente de extranjeros e improductivos. El Estado debía regirse por criterios económicos antes que electorales ${ }^{94}$ y debía hacer predominar a la fuerza sobre el consentimiento, la necesidad sobre la legalidad y la eficacia sobre la lógica. ${ }^{95}$ La opinión pública no debía tener influencia sobre las decisiones del Estado, sino que, por su propio bien y desarrollo, debía asumir y observar esa voluntad superior.

En todo el recorrido intelectual y político de Lugones se evidencia una concepción del Estado como instrumento exclusivo de cambio. La imposición del orden sólo podía obtenerse a partir de una transformación aguda de los valores y los comportamientos de los individuos y de la sociedad en su conjunto. El individuo debía ser impulsado — quizás sea mejor decir forzado- a transfigurarse, a pensarse articulado orgánicamente, no como sujeto sino como instrumento disciplinado y obediente.

Esa transformación, parece entender Lugones, tiene que ser lo suficientemente honda no sólo para hacer posible la imposición del orden, sino fundamentalmente para constituir estructuras psíquicas que, moldeadas bajo ese concepto de orden, se convirtieran en herramientas de su sostenimiento. En otras palabras, el poeta cordobés estaría apostando buena parte de sus esperanzas a un camino radicalizado y urgente de, como diría Norbert Elías, correspondencia entre el aparato de control y vigilancia de la sociedad y el aparato de control que se constituye en el espíritu del individuo. ${ }^{96}$

93 Lugones: Política Revolucionaria..., págs. 46-47.

94 Lugones: Política Revolucionaria..., pág. 47.

95 Lugones: Política Revolucionaria..., págs. 53-54.

96 Elias, Norbert: El proceso de la civilización, FCE, Buenos Aires, 1993, pág. 458. 